\section{SOI: 1.1/TAS DOI: $10.15863 /$ TAS International Scientific Journal Theoretical \& Applied Science}

p-ISSN: 2308-4944 (print) e-ISSN: 2409-0085 (online)

Year: 2017 Issue: 09 Volume: 53

Published: 5.09.2017 http://T-Science.org
Denis Chemezov

Master of Engineering and Technology, Corresponding Member of International Academy of Theoretical and Applied Sciences, Lecturer of Vladimir Industrial College, Russian Federation chemezov-da@yandex.ru

SECTION 6. Metallurgy and energy.

\title{
CONVECTIVE HEAT TRANSFER WHEN COOLING OF METALLIC MELTS
}

Abstract: The velocities fields of the convective flows of some metallic melts in conditions of the transition in the solid phase are presented in the article. The analysis of the castings quality made of steels, cast irons and nonferrous alloys after cooling was performed.

Key words: convective flow, cooling, a casting, hot tears.

Language: English

Citation: Chemezov D (2017) CONVECTIVE HEAT TRANSFER WHEN COOLING OF METALLIC MELTS. ISJ Theoretical \& Applied Science, 09 (53): 1-7.

Soi: http://s-o-i.org/1.1/TAS-09-53-1 Doi: crossef https://dx.doi.org/10.15863/TAS.2017.09.53.1

\section{Introduction}

The cooling process of metallic melts is accompanied by release of latent heat. Distribution of this heat during the phase transformation occurs by the expense of thermal conductivity of cooled melt, convection and radiation [1].

Convective heat transfer is performed by the convective flows arising when pouring of melt into the mould and acting on all the time range of the ingot crystallization [2]. Depending on the casting type and the casting configuration, the velocity of the convective flows may be different. It leads to the formation of the local volumes in the casting with less or more removed heat. The various kinds of the casting defects occur after cooling in the casting [3].

The problem solution of distribution of the convective flows in the volumes of metallic melts will allow to determine the mechanism of heat transfer and its influence on the casting crystallization $[4 ; 5]$.

\section{Materials and methods}

The calculation of the velocities of the convective flows was performed when cooling of alloy steel G21Mn5, carbon steel SS1505, corrosionresistant steel 321, grey cast iron EN-GJL-350, malleable cast iron EN-GJS-500, without tin bronze CC330G, brass C85700, aluminium foundry alloy AISi12 and zinc alloy ZA-27. The conditions of implementation of the computer modeling of the casting cooling are presented in the works $[6 ; 7]$.

\section{Results and discussion}

The results of the numerical simulations of the cooling process of melt are presented by the twodimensional fields of distribution of the convective flows in the volumes of the cylindrical castings. The velocities fields of the convective flows when cooling of grey cast iron EN-GJL-350 are presented in Fig. 1.

The yellow color on the fields is indicated the maximum velocities of the convective flows of melt, the blue color is the minimum velocities. The vectors indicate the movement direction of the convective flows in the volume of the casting.

On the first seconds of the cooling process of the ingot it is observed the chaotic movement of the convective flows. The intense convection occurs in the middle and in the surface layers of the casting. On the 39 second of the cooling process, the movement of the convective flows acquires the balanced character. The movement of the flows occurs bottom-up throughout the volume of the casting. The movement of the flows occurs top-down in the surface layers of the casting. On the 300 second the convective flows are weaken and concentrated mostly in the middle of the casting. At the same time the circulation process of the convective flows is continued right down to the end of the casting crystallization. 


\begin{tabular}{|c|c|c|c|c|c|c|}
\hline Impact Factor: & $\begin{array}{l}\text { ISRA (India) } \\
\text { ISI (Dubai, UAE } \\
\text { GIF (Australia) } \\
\text { JIF }\end{array}$ & $\begin{array}{l}=1.344 \\
=0.829 \\
=0.564 \\
=1.500\end{array}$ & $\begin{array}{l}\text { SIS (USA) } \\
\text { PИНЦ (Russia) } \\
\text { ESJI (KZ) } \\
\text { SJIF (Morocco) }\end{array}$ & $\begin{array}{l}=0.912 \\
=0.207 \\
=\mathbf{3 . 8 6 0} \\
=\mathbf{2 . 0 3 1}\end{array}$ & $\begin{array}{l}\text { ICV (Poland) } \\
\text { PIF (India) } \\
\text { IBI (India) }\end{array}$ & $\begin{array}{l}=6.630 \\
=1.940 \\
=4.260\end{array}$ \\
\hline
\end{tabular}

A)
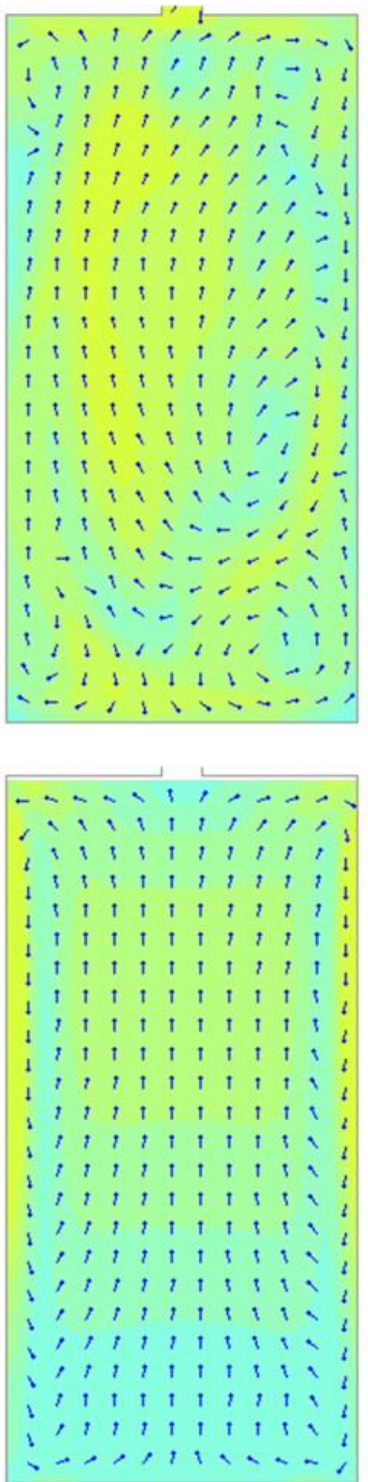

G)
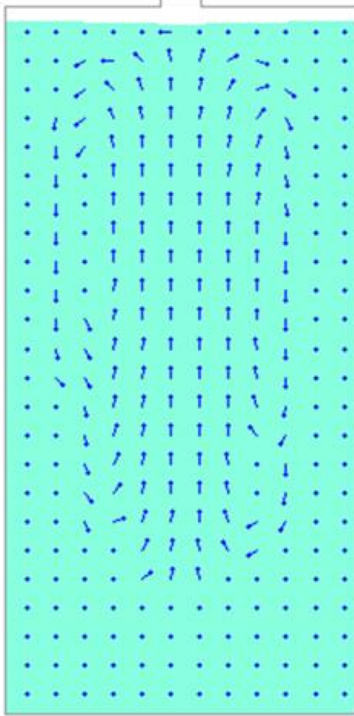
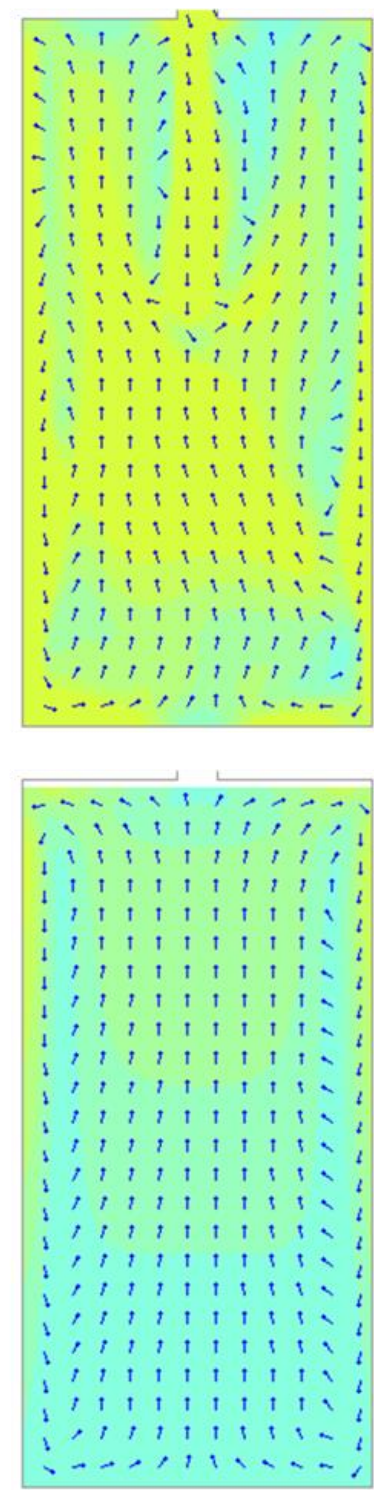

E)

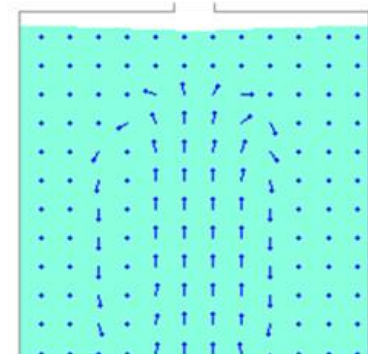

H)

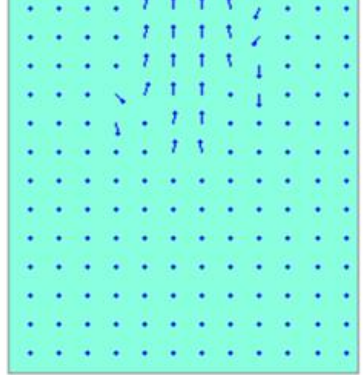

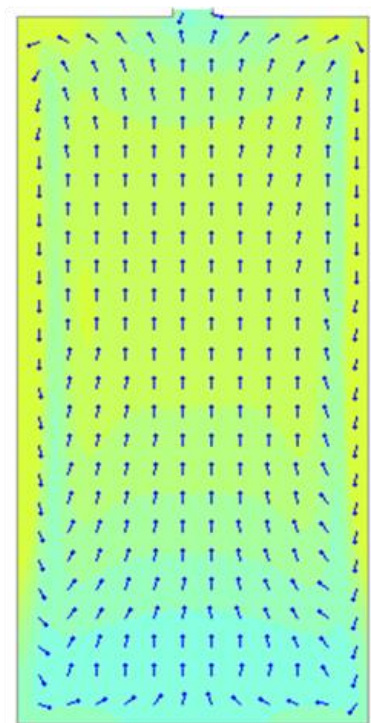

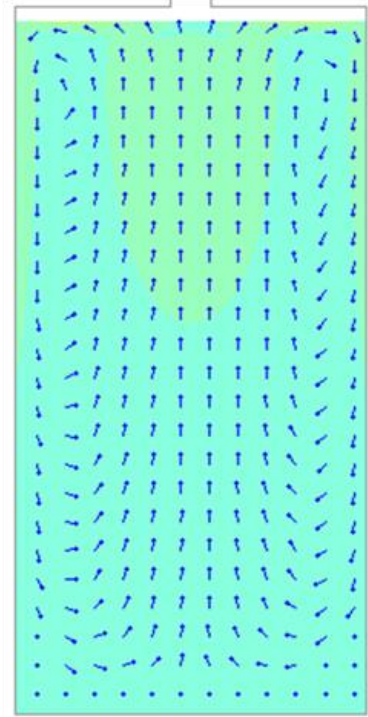

I)

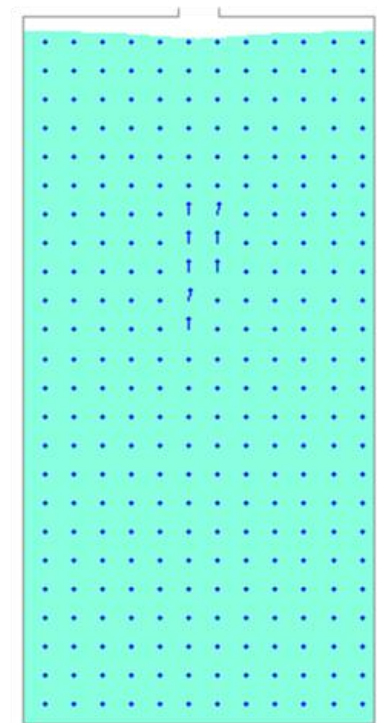

Figure 1 - The velocities of the convective flows when cooling of the iron casting with the display of the vectors: A - 0.001 s, B - 11.124 s, C - 39.755 s, D - 66.184 s, E - 99.922 s, F - 191.55 s, G - 300.137 s, H $356.951 \mathrm{~s}, \mathrm{I}-419.941 \mathrm{~s}$.

ISPC Innovations in science, 


\begin{tabular}{l|lrl|l|ll} 
& ISRA (India) & $=\mathbf{1 . 3 4 4}$ & SIS (USA) & $=\mathbf{0 . 9 1 2}$ & ICV (Poland) & $=\mathbf{6 . 6 3 0}$ \\
Impact Factor: & ISI (Dubai, UAE) $=\mathbf{0 . 8 2 9}$ & PUHU (Russia) $=\mathbf{0 . 2 0 7}$ & PIF (India) & $=\mathbf{1 . 9 4 0}$ \\
& GIF (Australia) & $\mathbf{0 . 5 6 4}$ & ESJI (KZ) & $=\mathbf{3 . 8 6 0}$ & IBI (India) & $\mathbf{4 . 2 6 0}$
\end{tabular}

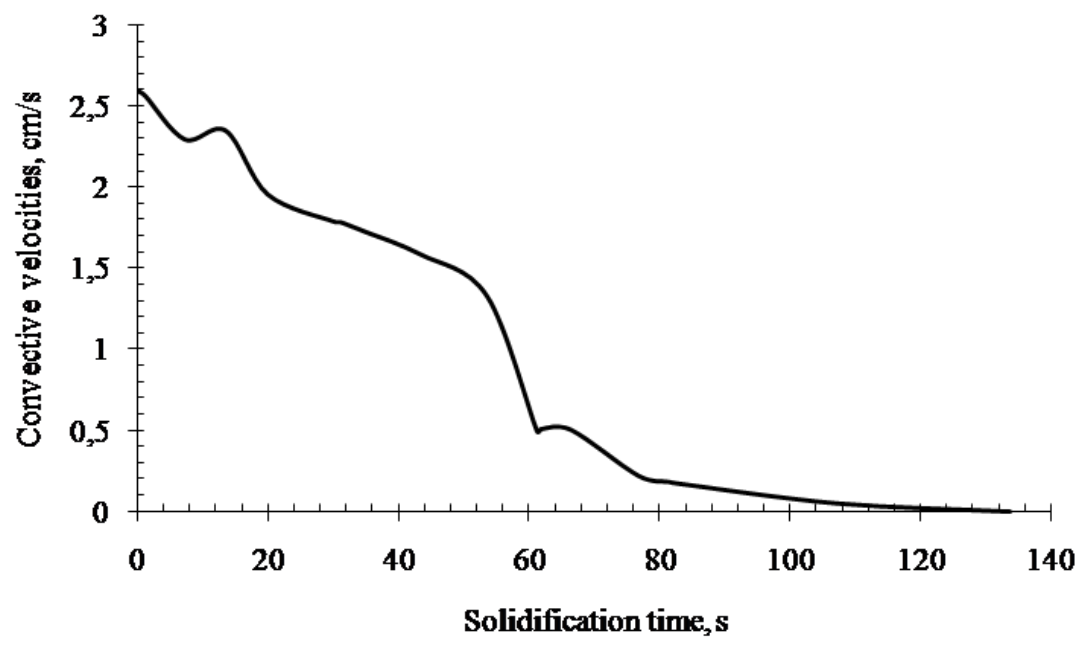

Figure 2 - The dependence of the velocities of the convective flows from solidification time of alloy steel G21Mn5.

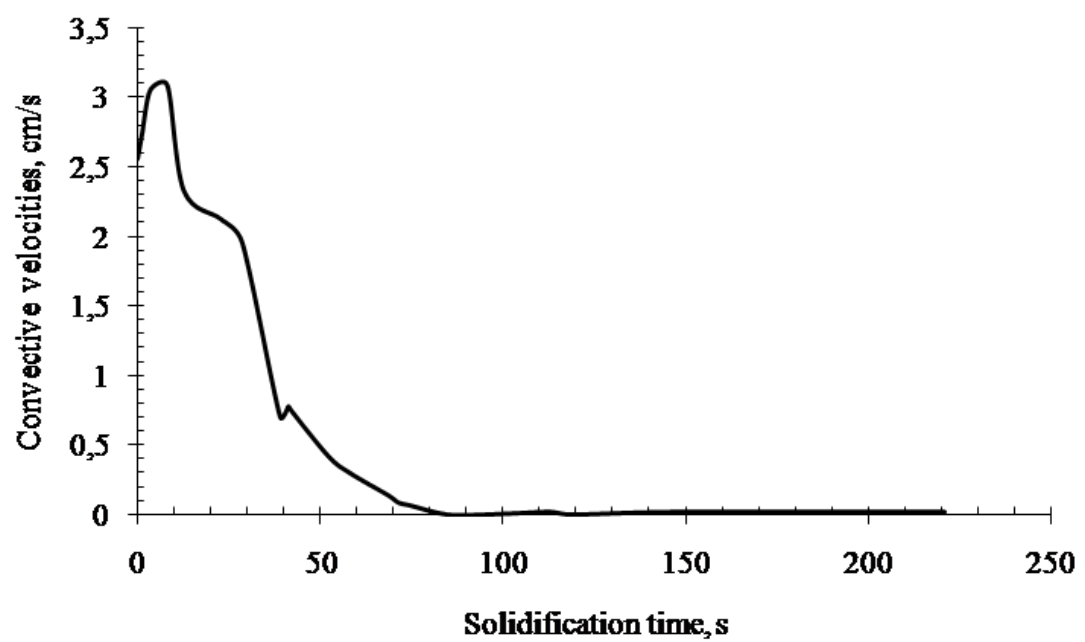

Figure 3 - The dependence of the velocities of the convective flows from solidification time of carbon steel SS1505.

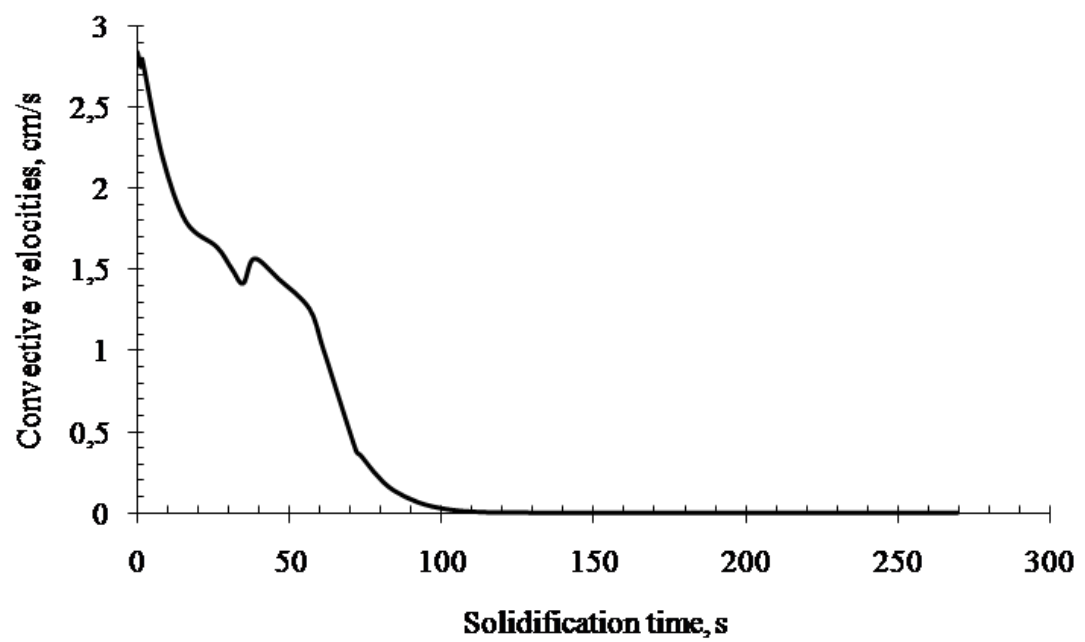

Figure 4 - The dependence of the velocities of the convective flows from solidification time of corrosionresistant steel 321 . 


\begin{tabular}{l|lrl|l|ll} 
& ISRA (India) & $=\mathbf{1 . 3 4 4}$ & SIS (USA) & $=\mathbf{0 . 9 1 2}$ & ICV (Poland) & $=\mathbf{6 . 6 3 0}$ \\
Impact Factor: & ISI (Dubai, UAE) $=\mathbf{0 . 8 2 9}$ & PUHU (Russia) $=\mathbf{0 . 2 0 7}$ & PIF (India) & $=\mathbf{1 . 9 4 0}$ \\
& GIF (Australia) & $\mathbf{0 . 5 6 4}$ & ESJI (KZ) & $=\mathbf{3 . 8 6 0}$ & IBI (India) & $\mathbf{4 . 2 6 0}$
\end{tabular}

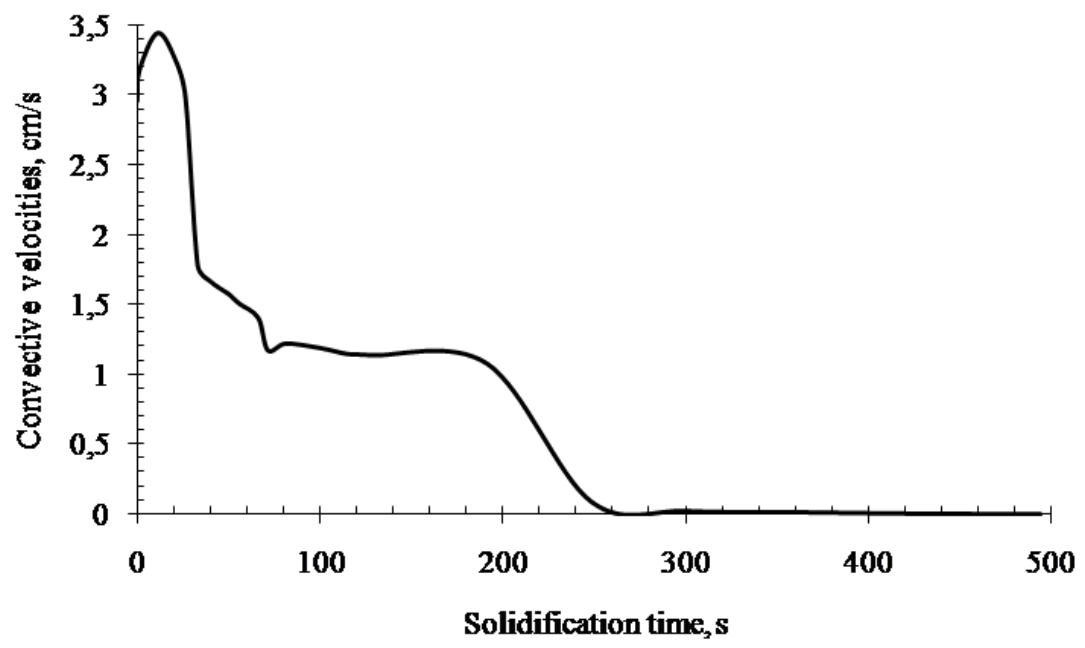

Figure 5 - The dependence of the velocities of the convective flows from solidification time of grey cast iron EN-GJL-350.

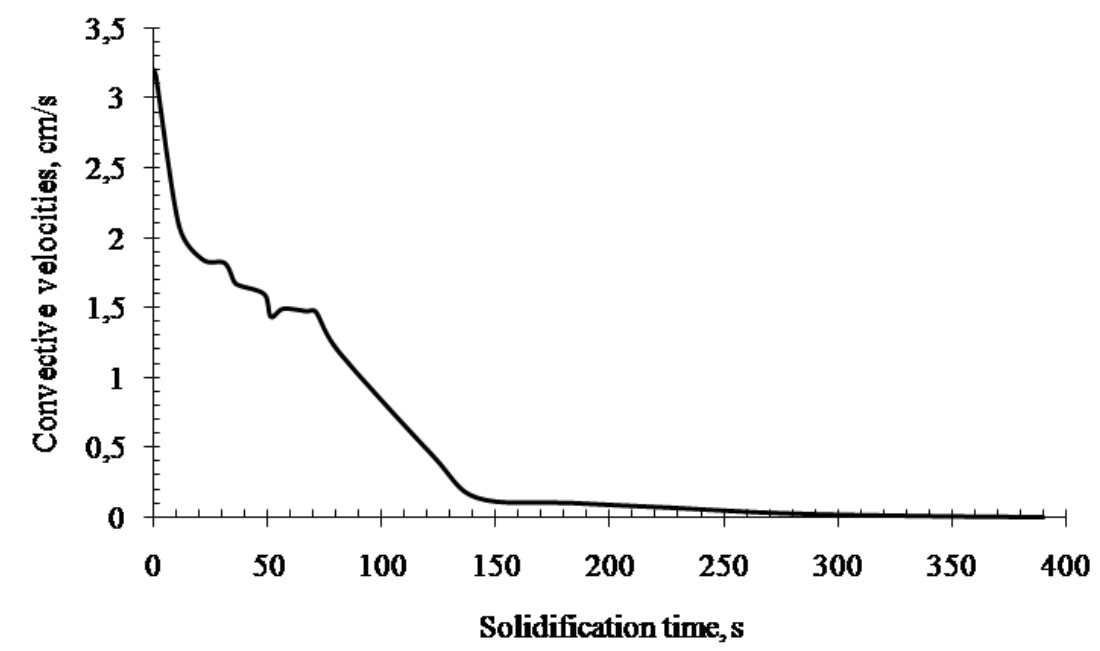

Figure 6 - The dependence of the velocities of the convective flows from solidification time of malleable cast iron EN-GJS-500.

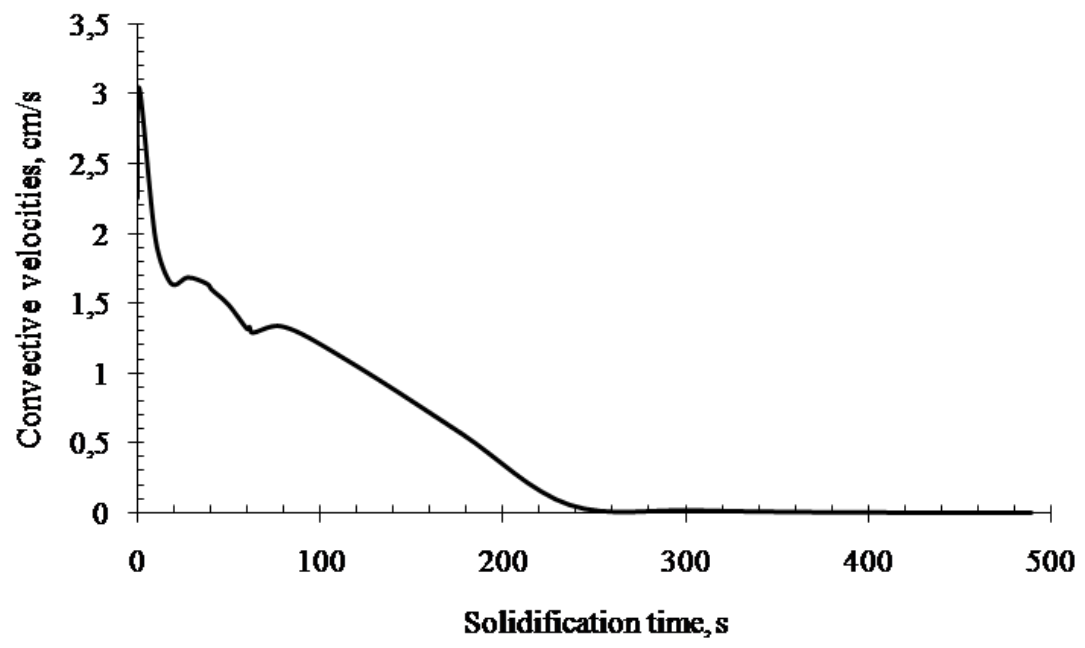

Figure 7 - The dependence of the velocities of the convective flows from solidification time of without tin bronze CC330G. 


\begin{tabular}{l|lrl|l|ll} 
& ISRA (India) & $=\mathbf{1 . 3 4 4}$ & SIS (USA) & $=\mathbf{0 . 9 1 2}$ & ICV (Poland) & $=\mathbf{6 . 6 3 0}$ \\
Impact Factor: & ISI (Dubai, UAE) $=\mathbf{0 . 8 2 9}$ & PUHU (Russia) $=\mathbf{0 . 2 0 7}$ & PIF (India) & $=\mathbf{1 . 9 4 0}$ \\
& GIF (Australia) & $\mathbf{0 . 5 6 4}$ & ESJI (KZ) & $=\mathbf{3 . 8 6 0}$ & IBI (India) & $\mathbf{4 . 2 6 0}$
\end{tabular}

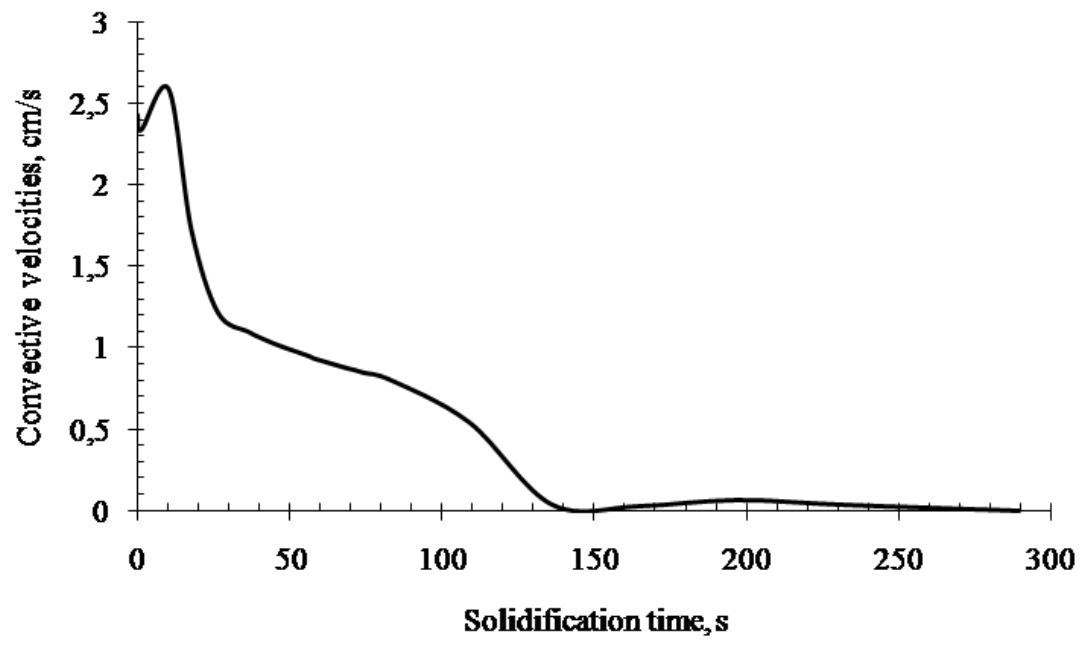

Figure 8 - The dependence of the velocities of the convective flows from solidification time of brass $\mathbf{C 8 5 7 0 0 .}$

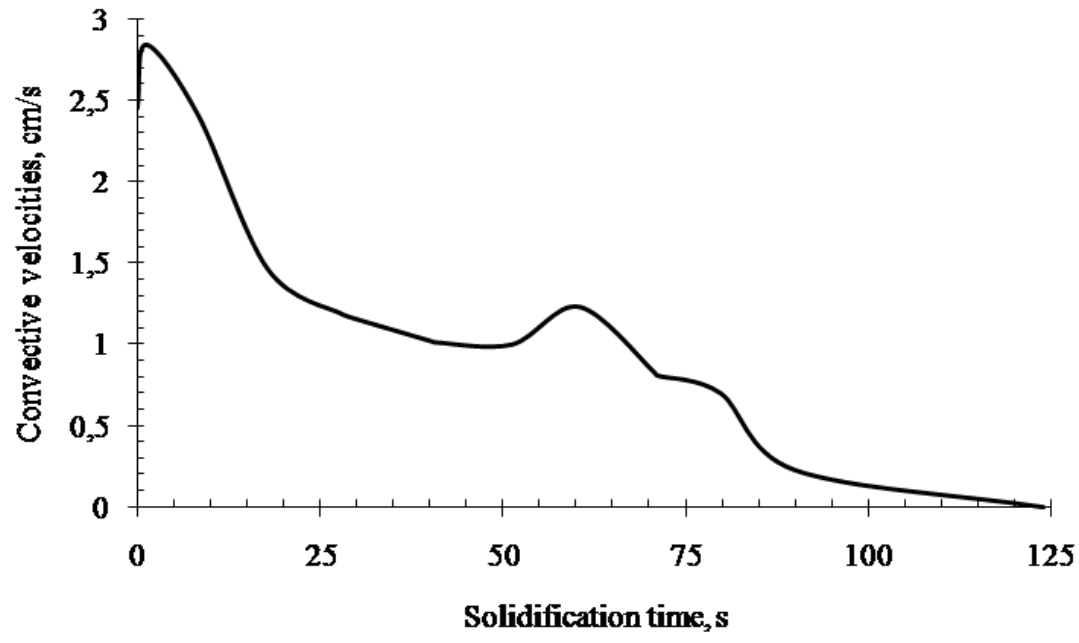

Figure 9 - The dependence of the velocities of the convective flows from solidification time of aluminium foundry alloy AISi12.

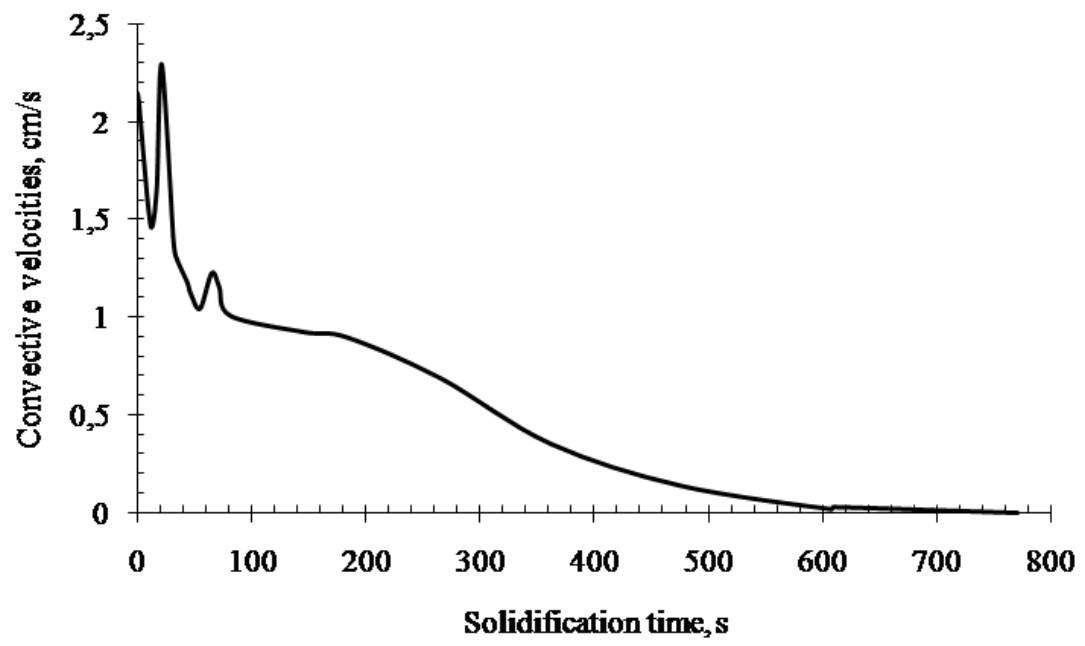

Figure 10 - The dependence of the velocities of the convective flows from solidification time of zinc alloy ZA27. 


\begin{tabular}{|c|c|c|c|c|c|c|}
\hline Impact Factor: & $\begin{array}{l}\text { ISRA (India) } \\
\text { ISI (Dubai, UAB } \\
\text { GIF (Australia) } \\
\text { JIF }\end{array}$ & $\begin{array}{r}=1.344 \\
=0.829 \\
=0.564 \\
=1.500\end{array}$ & $\begin{array}{l}\text { SIS (USA) } \\
\text { PИHЦ (Russia) } \\
\text { ESJI (KZ) } \\
\text { SJIF (Morocco) }\end{array}$ & $\begin{array}{l}=\mathbf{0 . 9 1 2} \\
=\mathbf{0 . 2 0 7} \\
=\mathbf{3 . 8 6 0} \\
=\mathbf{2 . 0 3 1}\end{array}$ & $\begin{array}{l}\text { ICV (Poland) } \\
\text { PIF (India) } \\
\text { IBI (India) }\end{array}$ & $\begin{array}{l}=6.630 \\
=1.940 \\
=4.260\end{array}$ \\
\hline
\end{tabular}

The values and intensity of the velocities of the convective flows when cooling of steels, cast irons and non-ferrous alloys are different. The velocity of the convective flows doesn't exceed of $4 \mathrm{~cm} / \mathrm{s}$ during gravity casting. The dependencies of the velocities of the convective flows from solidification time of metallic melts are presented in Figs. 2 - 10.

The maximum velocity of the convective flows is defined when cooling of grey cast iron EN-GJL350 , the minimum velocity is defined when cooling of zinc alloy ZA-27. The most long-lasting heat transfer occurs when cooling of zinc alloy ZA-27. The most active phase of convection in this alloy is observed on $2 / 3$ time range of the cooling process. Aluminium foundry alloy AISi12 is characterized by convective heat transfer on all the time range of the crystallization process.

The movement of the convective flows in melts of carbon steel SS1505 and corrosion-resistant steel 321 is calculated on 1/3 time ranges of the cooling process.
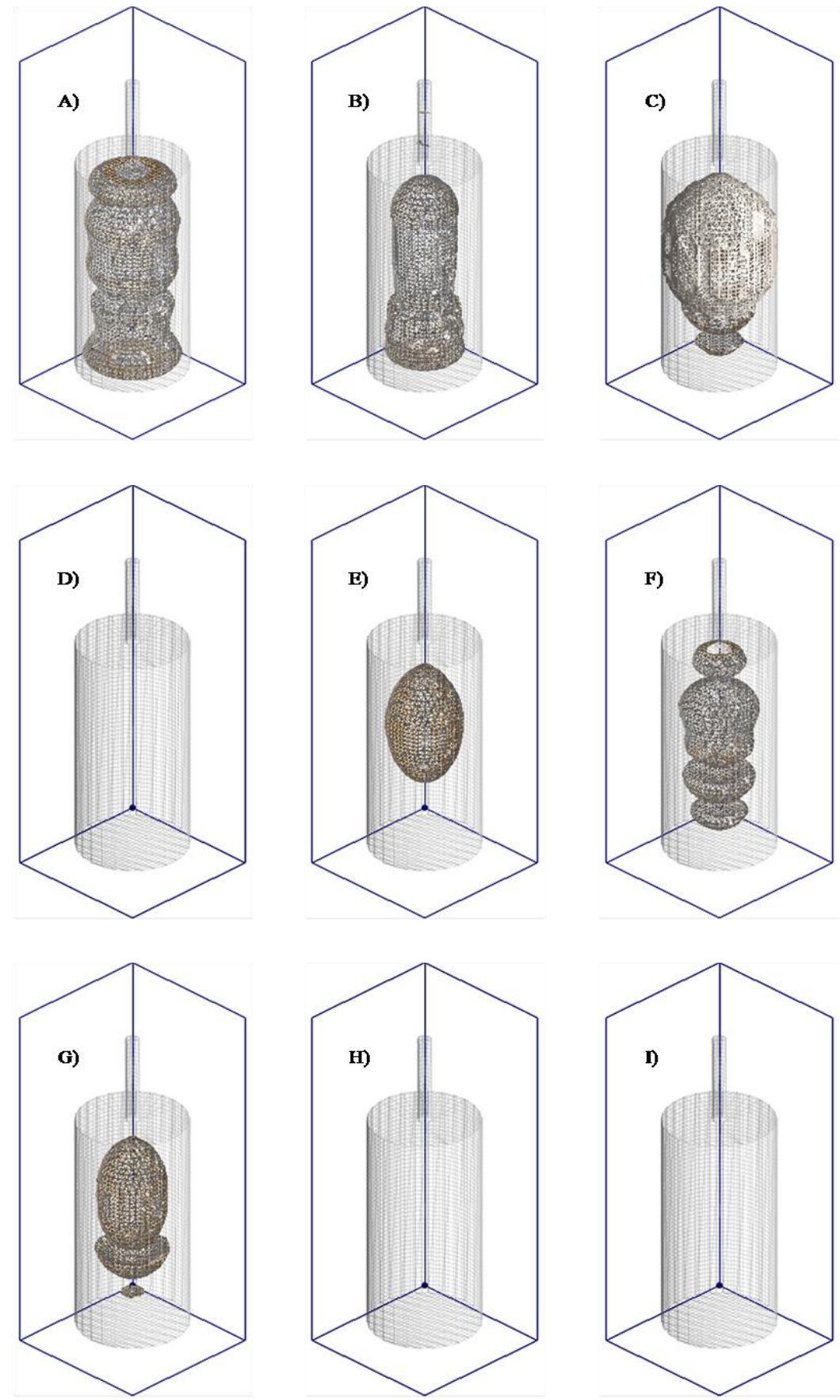

Figure 11 - Hot tears in the volumes of the castings: A - alloy steel G21Mn5, B - carbon steel SS1505, C corrosion-resistant steel 321, D - grey cast iron EN-GJL-350, E - malleable cast iron EN-GJS-500, F without tin bronze CC330G, G - brass C85700, H - aluminium foundry alloy AISi12, I - zinc alloy ZA-27.

ISPC Innovations in science, 


\begin{tabular}{l|lrl|l|ll} 
& ISRA (India) & $=\mathbf{1 . 3 4 4}$ & SIS (USA) & $=\mathbf{0 . 9 1 2}$ & ICV (Poland) & $=\mathbf{6 . 6 3 0}$ \\
Impact Factor: & ISI (Dubai, UAE) $=\mathbf{0 . 8 2 9}$ & PUHL (Russia) $=\mathbf{0 . 2 0 7}$ & PIF (India) & $=\mathbf{1 . 9 4 0}$ \\
& GIF (Australia) & $\mathbf{0 . 5 6 4}$ & ESJI (KZ) & $=3.860$ & IBI (India) & $=\mathbf{4 . 2 6 0}$
\end{tabular}

For the casting quality it is accepted the minimum formation of the casting defects in material [8]. Hot tears occur in the casting material from uneven cooling $[9 ; 10]$. Hot tears in the volumes of the castings after crystallization it is possible to research on the calculated three-dimensional fields (Fig. 11).

In the each three-dimensional field was located a wire model of the cylindrical casting, in which the calculated volume of material with hot tears is presented. Hot tears are the most pronounced in the middle of the casting. The volume value doesn't say about the size of hot tears. The maximum value of hot tears (22.881) was obtained after cooling of alloy steel G21Mn5, the minimum value (1.38) was obtained after cooling of without tin bronze CC330G. Hot tears in the castings made from grey cast iron EN-GJL-350, aluminium foundry alloy AISi12 and zinc alloy ZA-27 are virtually absent. The castings made of steels are the most exposed by hot tears.

\section{Conclusion}

The cooling process of the metallic casting is characterized by the interrelated processes of thermodynamics, hydrodynamics, heat transfer, phase transformation and solid mechanics. In conditions of gravity casting of the metallic castings with a simple configuration, the convective flows have the slow velocities. The movement of the convective flows has the circulation character to complete crystallization of the casting (for example, aluminium foundry alloy AISi12 and alloy steel G21Mn5). The high degree of the formation of hot tears in the casting made of alloy steel G21Mn5 is due to higher initial temperature of melt (in comparison with the initial temperatures other considered melts) and uneven cooling of the casting volume. The castings made of grey cast iron, aluminum and zinc alloys correspond by required quality to a greater extent.

\section{References:}

1. Timoshpolskij VI, Hopova OG, Ratnikov PE (2005) Analysis of different factors influencing on the processes of countercurrent radiationconvective heat exchange. Foundry production and metallurgy, (2-2): 62-66.

2. Demchenko EB (2012) About influence of convective melt flows on ingot hardening at horizontal continuous casting. Science and Technique, № 3. - pp. $11-16$.

3. Chaudhari S, Thakkar H (2014) Review on Analysis of Foundry Defects for Quality Improvement of Sand Casting. Int. Journal of Engineering Research and Applications, Vol. 4, Issue 3. - pp. $615-618$.

4. Trufanov NA, Shayakhmetova LR (2016) Numerical investigation of melt convection on the crystallization process of the ingot. Fundamental Research, № 1. - pp. $72-78$.

5. Balandin GF (1998) The theory of the formation of the casting. Fundamentals of the theory of heat. The solidification and cooling of castings. Moscow, MSTU Bauman. - 360 p.

6. Chemezov D (2017) Shrinkage of some metal alloys after solidification. ISJ Theoretical \& Applied Science, 06 (50): 87-89. Soi: http://s-oi.org/1.1/TAS-06-50-10 Doi: https://dx.doi.org/10.15863/TAS.2017.06.50.10

7. Chemezov D (2017) The degree of shrinkage porosity in the castings after solidification. ISJ Theoretical \& Applied Science, 07 (51): 1-6. Soi: http://s-o-i.org/1.1/TAS-07-51-1 Doi: https://dx.doi.org/10.15863/TAS.2017.07.51.1

8. (1986) GOST 4.439-86. Product-quality index system. Castings. Index nomenclature.

9. Monroe C, Beckermann C (2005) Development of a Hot Tear Indicator for Steel Castings. Materials Science \& Technology. - pp. 47 - 56.

10. (2017) Casting Defects: Hot Tearing. Available: http://www.totalmateria.com/page.aspx?ID=Ch eckArticle\&NM=204\&site $=$ ktn $\quad$ (Accessed: 30.08.2017). 